\title{
ARMEN- EN KERKEZORG IN SURINAME NA DE INBEZITNEMING DER KOLONIE DOOR ABRAHAM CRYNSSEN
}

DOOR

\section{FRED. OUDSCHANS DENTZ}

Twee jaren na de inbezitneming van Suriname lezen wij in de politieke notulen van 17 Juni 1669: „Op seeker request van den Kerckenraedt van Suriname, gepresenteert tot soustien en onderhoudt van de armen in deze provincie, sijn toegestaen de naevolgende poincten:

1. dat alle drie maenden een collecte sal mogen gedaen worden door de gansche provincie ende dat de Kerckenraedt daartoe sodanige personen toe sullen gebruijken, die sij sullen denken bequaem te weesen;

2. dat op alle obligatien en assignatien die geaccepteert sijn bij manquement van betaling een parate executie sal volgen;

3. dat alle incomende schepen sullen gehouden sijn voor den armen te geven hondert pondt broodt of de valeur van hondert pondt suijcker;

4. dat voor yeder vijftich ackers landt die tot Toerarica sal opgenomen worden, hondert pondt suijcker van den opnemer voor den armen betaelt sal worden;

5. dat yeder herbergier jaerlijcks voor de armen sal geven driehondert pondt suijcker;

6. dat voor yeder persoon, die in de Kerck sal begraven worden, sal voor de armen betaelt worden vierhondert pondt suijcker.

De eerste diaken was de commies Combé. Omtrent zijn dienst als commies werd in hetzelfde jaar 1669 bepaald, hoe hij de schepen heeft te visiteeren: „Hy sal sich aen boort begeven en sich informeeren van den naem van den schipper en het schip en waer het van daen is, alsmede van de ladinge, dewelcke indien bestaet in neegers, koebeesten of paerden, sal correct het getal 
daervan opnemen, doch in cas bestaet in alderhande andere coopmanschappen sal met het simpele antwoort van de schippers tevreden syn ende voorts alles net te boek stellen. Voor de passe om aen den sergeant in het fort de wacht hebbende te vertoonen, sal de commijs genieten dertich stuyvers".

Combé heeft voor de armen veel weten te doen, behalve dat hij met zijn visitatie ten behoeve van de belasting voor de inning van de noodige gelden zorgde. Toen de armenkas goed voorzien was en de kerkekas in minder goeden staat verkeerde, kreeg hij gedaan, dat de $f 5$.-, welke ieder vertrekkend schip of bark aan de armen betaalde, aan de kerkekas zou worden overgedragen. Combé was toen - in 1690 - kerkmeester.

Wij lezen op 8 April 1690: ,,binnengestaen Nicolaes Combé, kerckmeester van de kercke alhier aen Paramaribo. Volgens resolutie van 2 Juni voorleden jaer heeft hij provisioneel eenige gelden uit de effecten van den armen genomen tot reparatie van de voormelde kercke" en hij deelt mede ,,dat dewijl als nu de gelden van den voorsegden armen heeft overgelevert aen de diaconen die in sijn plaets aengestelt waerdoor sigh daervan alsnu niet conde bedienen en de kerck geen middelen hadt om de nodige reparatie te kunnen betaelen" verzoekt hij ,,dat naerdemael de effecten van den armen seer considerabel en wijnigh armen sijn dat de Heeren deser taeffel de goedheijt beliefden te hebben om aen de voorsegde kercke toe leggen soodanige vijf guldens als ijder schipper ende sijn schip of barck uyt dese riviere vertreckende aen den voorsegden armen moeten betaelen". Waarop gedelibereert sijnde is goetgevonden en verstaen dat yder van hier vertreckende schipper met sijn schip ofte barck de vijf guldens in plaets van aen den armen aen den voorsegden Nicolaes Combé als kerckmeester sal moeten betaelen".

De mededeeling betreffende de ,considerabele" middelen van de diaconie, door Combé in den Raad gedaan, ontging den gouverneur en raden niet. Enkele weken later wordt „op voorstel van den Gouverneur goetgevonden en verstaen de armmeesters of diaconen deser stede te ordonneeren, dat sy haer sullen hebben te prepareeren tot het besorgen van soodanige posten, plancken en hout, als tot het bouwen van een provisioneel hospitael soude werden gerequireert, en dat van soodanige groote als de Heer Gouverneur goetvinden sal te moeten syn". 